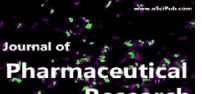

\title{
Effect of Ricinodendron heudelotii seed extract on the oxidative stress biomarkers of Diabetic albino rats
}

\section{Odinga, T., ${ }^{1,2}$, Nwaokezi, C.O. ${ }^{1}$}

${ }^{1}$ Department of Biochemistry, Rivers state university. Nigeria;

${ }^{2}$ Department of Biochemistry, University of Port Harcourt, Rivers state, Nigeria.

\section{ABSTRACT}

This study evaluated the potentials of the seed extract of Ricinodendron heudelotii on the oxidative stress biomarkers of diabetic albino rats of the wistar strain. Diabetes mellitus was induced via intraperitoneal administration of $160 \mathrm{mg} / \mathrm{kg}$ bodyweight Alloxan monohydrate in normal saline and confirmed after 120 hours of blood glucose level above $300 \mathrm{mg} / \mathrm{dl}$. Blood samples were collected from the animals and analyzed for Malondialdehyde, Catalase, Reduced Glutathione, GlutathioneS-transferase, Glutathione peroxidase, and Superoxide dismutase activities as biomarkers of oxidative stress. The result revealed a significant decrease at $\mathrm{P} \leq 0.05$ in blood glucose concentration of diabetic rats with increase in the seed extract concentration, Malondialdehyde (MDA) decreased significantly in the diabetic rats while Catalase increased significantly at $\mathrm{P} \leq 0.05$ as the extract concentration increased. Variations in GlutathioneS-transferase, Glutathione Peroxidase, Superoxide dismutase and Reduced Glutathione in comparison with control was observed. The results therefore suggests that the aqueous seed extract of Ricinodendron heudelotii has the potency to reduce glucose level and act as antioxidants against oxidative stress, hence its use therapeutically.

Keywords: Ricinodendron heudelotii, Alloxan monohydrate, Antioxidant biomarkers, Diabetes mellitus, oxidative stress.

\section{${ }^{*}$ Correspondence to Author:}

Odinga Tamuno-boma ${ }^{1,2}$

${ }^{1}$ Department of Biochemistry, Rivers state university. Nigeria; ${ }^{2} \mathrm{De}$ partment of Biochemistry, University of Port Harcourt, Rivers state, Nigeria.

\section{How to cite this article:}

Odinga, T., Nwaokezi, C.O. Effect of Ricinodendron heudelotii seed extract on the oxidative stress biomarkers of Diabetic albino rats. Journal of Pharmaceutical Research and Reviews, 2020; 4:19

\section{eScîPub}

eSciPub LLC, Houston, TX USA. Website: https://escipub.com/ 


\section{Introduction}

There is an alarming need for the use of alternative remedies in the treatment of diseases. This is due to the beneficial effect that plants exert through the additive or synergistic action of several chemical compounds acting at single or multiple target sites associated with a physiological process as reported by (Singh, 2011; Odinga et al., 2016) yet with less or no side effects, its affordability and availability(Firdous, 2014). In their research, Odinga et al., 2016 found that the plant seed of Ricinodendron heudelotii contains some phytochemicals such as Tannin, Lunamarine, Ribalidine, Spogenin, Catechin, Rutin, Epicatichin, Kaempferol, Naringenin, amongst others. These phytochemicals exhibit various functions such as anti-inflammatory, anti-oxidant, anti-platelet, anti-allergic (Johnson et al., 2012) and anti-ulcer (Odinga et al., 2018).

Oxidative stress is being considered as a common pathogenic factor in diabetes mellitus and its complications (Wang, 2011; Griendling and Fitzgerd, 2003; Harrison et al., 2003; Mueller et al., 2005). The most important free radicals that causes oxidative stress are superoxide, hydroxyl radical and hydrogen peroxide. In human, there are antioxidant enzymes like superoxide dismutase (SOD), catalase, and glutathione (GSH) and its enzymes such as glutathione reductase (GR), glutathione peroxidase (GPx) \& glutathione-stransferase, which scavenges the action of free radicals in order to protect the body. When the generation of reactive oxygen species (ROS) exceeds cellular defense mechanisms, these unstable molecules interact with biologic macromolecules such as lipids, proteins and DNA and lead to structural changes as well as functional abnormalities. Edwin et al., 2013 described biomarkers of oxidative stress as molecules that are modified when interacting with Reactive Oxygen Species in the micro environment and molecules of the antioxidant system that change in response to increased redox stress.
Adrogue et al., 1986 associated Diabetes with an unbalanced production of Reactive Oxygen Specie.

Antioxidants: are the compounds that protect the body against toxic effect of free radicals. The protective mechanisms of antioxidants serve to scavenge the free radicals. Different antioxidants act at different levels:

- They may prevent the initiation of chain reactions by removing free radicals.

- They may scavenge free radicals generated in chain reactions, thereby interrupting the chain sequence.

- They may remove peroxides, thereby preventing further generation of reactive oxygen species

(ROS).

Superoxide dismutase (SOD): These enzymes catalyze the conversion of highly reactive superoxide radical $\left(\mathrm{O}_{2}^{-}\right)$to relatively less toxic hydrogen peroxide. They acts as first line of defense to protect the tissues from the toxic effects of superoxide radicals.

Catalase: protects the tissues from toxic effect of $\mathrm{H}_{2} \mathrm{O}_{2}$. Catalase is present in peroxisomes. The $\mathrm{H}_{2} \mathrm{O}_{2}$ which is generated by SOD can be scavenged by catalase. Catalase decomposes hydrogen peroxide to water and oxygen.

Malondialdehyde (MDA) is generated in vivo via peroxidation of polyunsaturated fatty acids. It interacts with proteins and is itself potentially atherogenic. MDA's reaction with lysine residues generates lysine-lysinecross-links (Uchida, 2000) which have been identified in apolipoprotein $\mathrm{B}(\mathrm{apoB})$ fractions of oxidized low density lipoprotein(OxLDL), and have been postulated to impair the interaction between OxLDL and macrophages and thereby to promote atherosclerosis (Slatter et al., 2000).

Glutathione peroxidase is a selenium containing enzyme. It catalyzes the reduction of hydrogen peroxide $\left(\mathrm{H}_{2} \mathrm{O}_{2}\right)$ and lipid hydroperoxides using reduced glutathione (GSH) as the reducing agents. During reduction of $\mathrm{H}_{2} \mathrm{O}_{2}$ and lipid hydroperoxide, reduced glutathione is 
converted into oxidized glutathione. The oxidized glutathione is then reduced by glutathione reductase which requires coenzyme $\mathrm{NADPH}$.

\section{MATERIALS AND METHODS}

Plant Material: The dried seeds of Ricinodendron heudelotii were purchased from a local market in Port Harcourt, identified and authenticated in the Department of Plant Science and Biotechnology, University of Port Harcourt. The clean seeds were pulverized into powder.

Preparation of Extract: The ground powder was subjected to extraction using $99 \%$ ethanol in the ratio of 1:3 ground powder to ethanol. After 72 hours, the mixture was filtered using whatman number 1 filter paper and the extract was allowed to concentrate in a water bath at 92 degree Celsius to obtain a pure extract. The extract was stored at freezing temperature prior to its use for administration to the experimental animals.

\section{DIABETES INDUCEMENT/EXPERIMENTAL DESIGN}

The method of Abdel-Hassan et al., 2001 was adopted. Thirty Wistar albino rats of weight 150$200 \mathrm{~g}$ were used. The animals were fasted overnight; diabetes mellitus was induced by intraperitoneal administration of $160 \mathrm{mg} / \mathrm{kg}$ Alloxan monohydrate in normal saline. The diabetic states of the rats were confirmed 120 hours after administering the alloxan to groups 2-6 of the experimental animals, with group one not induced and served as control. Diabetes Mellitus was confirmed after 120 hours of blood glucose level above $300 \mathrm{mg} / \mathrm{dl}(8.5 \mathrm{mmol} / \mathrm{l})$ by collection of blood from the tail of each animal using surgical blade. The blood was dropped on the strip to determine their blood glucose level as described by Al-Hader et al., 1994.

Varied doses of aqueous extract of Ricinodendron heudelotii (500, 1000, 1500 $\mathrm{mg} / \mathrm{kg}$ body weight), fixed dose of standard drug (Metformin) against hyperglycemia $(500 \mathrm{mg} / \mathrm{kg}$ body weight) as positive control, the negative group that was left untreated and the treated groups. The extract was administered orally 24 hourly to the appropriate groups and were monitored at intervals for 21 days. The percentage reduction in blood glucose level of animals was computed for each dose of extract, the standard drug, the untreated group and the control. The blood of the rats were collected on Sample bottles and investigated for the oxidative stress biomarkers.

\section{Administration of Extract and Treatment of the Animals}

The experimental animals were grouped as follows:

Group 1: Normal control - Non-diabetic animals (Rat feed + water)

Group 2: Positive control - Diabetic animals (500 $\mathrm{mg} / \mathrm{kg}+$ Metformin).

Group 3: Negative control - Diabetic animals not treated.

Group 4-6 Diabetic animals treated with seed extract concentrations $(500,1000$, and 1500) $\mathrm{mg} / \mathrm{kg}$ respectively.

Metformin, a standard anti-diabetic drug and the seed extract at all concentrations were administered to the animals by oral intubation for 21 days 24 hourly. All groups were allowed commercial feed and water ad libitum for the 21 days study period. The fasting glucose level for the rats in each group was monitored at 7 days interval. The experimental animals were sacrificed via cervical dislocation. Blood collection for glucose estimation was by vein puncture technique. A sterile lancet was used to puncture the tail vein of the rats. Blood glucose was assayed by the glucose oxidase method, using a glucometer. The Oxidative stress biomarkers were analyzed thus:

Catalase (CAT): Catalase was colorimetrically determined using a catalase assay kit containing a stopping solution. The stop solution caused the complete stop of catalase activity. Catalase content of the samples reacted firstly with hydrogen peroxide to produce water and oxygen and the unconverted hydrogen peroxide reacted 
with OxiRed probe solution to produce a product which was measured at $570 \mathrm{~nm} .12 \mu \mathrm{L} 1 \mathrm{mM}$ fresh hydrogen peroxide solution was added to $40 \mu \mathrm{L}$ serum samples or high control serum samples (HC sample); stopping solution was firstly added to $\mathrm{HC}$ serum samples and then the catalase activity was assayed. All samples were incubated at $25^{\circ} \mathrm{C}$ for $30 \mathrm{~min}$ and then $10 \mu \mathrm{L}$ stop solution was added into sample vials. $\mathrm{HC}$ and standard samples already contained the stop solution. OxiRed probe solution was added to the samples and incubated at $25^{\circ} \mathrm{C}$ for $10 \mathrm{~min}$. Then, the absorbance at $570 \mathrm{~nm}$ was measured. A standard curve was prepared by adding $10 \mu \mathrm{L}$ stop solution to $0,2,4,6,8$ and $10 \mu \mathrm{L} 1 \mathrm{mM}$ hydrogen peroxide solution.

Malondialdehyde (MDA): MDA level in serum was assessed by the new colorimetric method of Satoh, 1978. After the reaction of thiobarbituric acid with malondialdehyde, the reaction product was extracted in butanol and was measured.

Superoxide Dismutase (SOD): SOD levels in plasma were estimated by the method of Marklund and Marklund, 1974, modified by Nandi and Chatterjee, 1988. The ability of superoxide dismutase to inhibit the autooxidation of epinephrine at $\mathrm{pH} 10.2$ has been used as the basis of a convenient and sensitive assay for the SOD enzyme.

Reduced Glutathione (GSH): GSH levels in blood were assessed using 5-5-dithiobis-2dinitrobenzoic acid (DTNB) by the method of Beutler et al., 2000.

Glutathione peroxidase (GPx): Glutathione peroxidase activity in blood was estimated by the method of Paglia and Valentine using $\mathrm{H}_{2} \mathrm{O}_{2}$ as a substrate.

\section{Results and Discussion}

Table 1: Effect of Ricinodendron heudelotii seed aqueous extract on induced diabetic experimental rats

\begin{tabular}{lllllll}
\hline & GROUP 1 & GROUP 2 & GROUP 3 & GROUP 4 & GROUP 5 & GROUP 6 \\
\hline Before inducement (mmol/l) & $4.22 \pm 0.75^{\mathrm{a}}$ & $5.40 \pm 0.74^{\mathrm{a}}$ & $3.96 \pm 0.89^{\mathrm{a}}$ & $3.96 \pm 0.27^{\mathrm{a}}$ & $5.14 \pm 0.38^{\mathrm{a}}$ & $3.70 \pm 0.40^{\mathrm{a}}$ \\
After Inducement (mmol/L) & $4.22 \pm 0.75^{\mathrm{a}}$ & $5.02 \pm 0.85^{\mathrm{b}}$ & $8.26 \pm 6.47^{\mathrm{b}}$ & $5.36 \pm 2.89^{\mathrm{b}}$ & $13.08 \pm 11.64^{\mathrm{b}}$ & $10.50 \pm 8.91^{\mathrm{b}}$ \\
After Treatment (mmol/L) & $4.22 \pm 0.75^{\mathrm{a}}$ & $4.58 \pm 0.81^{\mathrm{c}}$ & $11.92 \pm 8.49^{\mathrm{c}}$ & $5.46 \pm 1.54^{\mathrm{b}}$ & $4.92 \pm 0.69^{\mathrm{c}}$ & $10.06 \pm 4.49^{\mathrm{b}}$ \\
\hline
\end{tabular}

- Values are expressed as mean \pm standard deviation.

- Values with different superscripts show significant difference at the 0.05 level.

- Values with the same superscripts shows no significance at the 0.05 level.

The presence of phytochemicals was reported by Odinga et al., 2016 in the seed extract of Ricinodendron heudelotii and was used in the treatment of induced diabetes in this study. From table 1 above, it is observed that the ability of the extract to reduce the induced blood glucose level was concentration dependent. The most reducing ability was at $1000 \mathrm{mg} / \mathrm{kg}$ body weight of the extract. Group 3 which is the negative control, had an increased blood glucose level. This may be due to the non-administration of the extract to the rats in the group. Alloxan increases blood glucose level by attacking the pancreas, thus depleting the beta cells responsible for glucose metabolism (Sedighi et al., 2014). The effectiveness of the extract to reduce the blood glucose level of the experimental animals could be attributed to the extracts ability to stimulate the pancreatic beta cells to release insulin due to the presence of the phytochemical constituent of the seed (Shlafer and Marieb, 1989). This mechanism corresponds to the function of the oral hypoglycemic agents such as metformin, sulphonylureas. This study hence suggests the potency of Ricinodendron heudelotii as a therapy for hyperglycemia. 
Odinga, T. and Nwaokezi, C.O., JPRR, 2020;4:19

Table 2: Effect of Ricinodendron heudelotii seed aqueous extract on the oxidative stress biomarkers of induced diabetic experimental rats

\begin{tabular}{lclllll}
\hline GROUP & MDA & CAT & GSH & GST & GPx & SOD \\
\hline 1 & $1.41 \pm 0.702^{\mathrm{a}}$ & $4.90 \pm 2.371^{\mathrm{a}}$ & $2.68 \pm 0.171^{\mathrm{a}}$ & $0.77 \pm 0.031^{\mathrm{a}}$ & $0.25 \pm 0.029^{\mathrm{a}}$ & $0.32 \pm 0.223^{\mathrm{a}}$ \\
2 & $1.07 \pm 0.218^{\mathrm{b}}$ & $4.50 \pm 0.529^{\mathrm{b}}$ & $2.93 \pm 0.171^{\mathrm{a}}$ & $0.74 \pm 0.054^{\mathrm{a}}$ & $0.33 \pm 0.057^{\mathrm{b}}$ & $0.31 \pm 0.071^{\mathrm{a}}$ \\
3 & $1.03 \pm 0.385^{\mathrm{b}}$ & $6.35 \pm 0.755^{\mathrm{b}}$ & $2.75 \pm 0.173^{\mathrm{a}}$ & $0.72 \pm 0.017^{\mathrm{a}}$ & $0.29 \pm 0.029^{\mathrm{c}}$ & $0.25 \pm 0.071^{\mathrm{a}}$ \\
4 & $1.39 \pm 0.350^{\mathrm{a}}$ & $5.78 \pm 1.135^{\mathrm{b}}$ & $2.93 \pm 0.096^{\mathrm{a}}$ & $0.71 \pm 0.038^{\mathrm{a}}$ & $0.31 \pm 0.029^{\mathrm{c}}$ & $0.34 \pm 0.119^{\mathrm{a}}$ \\
5 & $1.27 \pm 0.542^{\mathrm{c}}$ & $7.72 \pm 0.899^{\mathrm{b}}$ & $2.75 \pm 0.129^{\mathrm{a}}$ & $0.68 \pm 0.036^{\mathrm{b}}$ & $0.24 \pm 0.041^{\mathrm{d}}$ & $0.14 \pm 0.049^{\mathrm{b}}$ \\
6 & $0.71 \pm 0.568^{\mathrm{d}}$ & $11.83 \pm 3.006^{\mathrm{b}}$ & $2.95 \pm 0.191^{\mathrm{a}}$ & $0.70 \pm 0.035^{\mathrm{a}}$ & $0.34 \pm 0.021^{\mathrm{e}}$ & $0.24 \pm 0.180^{\mathrm{a}}$
\end{tabular}

- Values are expressed as mean \pm standard deviation.

- Values with different superscripts show significant difference at the 0.05 level.

- Values with the same superscripts shows no significance at the 0.05 level.

Table 2 shows the oxidative stress biomarkers of Diabetic experimental albino wistar rats treated with varying extracts of aqueous seed extract of Ricinodendron heudelotii. Malondialdehyde was observed to decrease significantly with increase in concentration of seed extract in comparison with the control, with an exception of rats in group 4.

Gawel et al., (2004) reported that an increase in free radical causes an overproduction of MDA which is a marker of oxidative stress. The concentration for Catalase was observed to increase with increase in concentration of the seed extract when compared with the control.

Somani et al., 2007 reported that increased oxidative stress that occurs with aging in mice is alleviated by over expression of Catalase. Also that a deficiency of the catalase which is found in all organisms exposed to oxygen increases the likelihood of developing obesity, fatty liver and type 2 diabetes, hence, the result suggests that Ricinodendron heudelotii possess the potency to increase serum Catalase. The reduced glutathione concentration was observed to have same trend as that of Catalase. Pompella et al., 2003 reported that Glutathione is capable of preventing damage to important cellular components caused by reactive oxygen species such as free radicals, peroxides, lipid peroxides, and heavy metals.

\section{Conclusion}

The findings of this study suggests that the aqueous seed extract of Ricinodendron heudelotii has the potency to reduce the glucose level of wistar albino rats and has antioxidant effects against oxidative stress in wistar albino rats, hence the plant extract could be used as an effective therapeutic agent in the management of diabetic condition.

\section{References}

1. Abdel-Hassan, I. A., Abdel-Barry, J. A. and Mohammed, S. T. (2001). The hypoglycemic and anti-hyperglycemic effect of Citrullus colocynthis fruit aqueous extract in normal and alloxan diabetic rabbits. Journal of Ethnopharmacology. 71; 325-330.

2. Adrogue, H. J., Ledere, E. D., Suki, W. N. and Eknoyan, G. (1986). Determination of plasma potassium levels in diabetic ketoacidiosis. Medicine 65:163-172.

3. Al-Hader, A. A., Hasan, Z. A. And Agel, M. B. (1994). Hypoglycemic and insulin release inhibitory effect of Rosemorinus officialis. Journal of Ethnopharmacology. 43; 217-222.

4. Beutler, E., Duron, O. and Kelly, B. M.(1963). Improved method for the determination blood glutathione. J. Lab. Clin Med. 61:882-8. PMid:13967893. 
Odinga, T. and Nwaokezi, C.O., JPRR, 2020;4:19

5. Edwin, H., Keyvan, K. G., Chia-Chi, L., Ravi, B. and Gemma, A. F. (2013). Biological markers of oxidative stress: Applications to cardiovascular research and practice. Redox Biology 1(1): 483491

6. Firdous, S. M. (2014). Phytochemical for treatment of diabetes. Excli Journals. 13; 451-453.

7. Gawel, S., Wardas, M., Nieedworok, E. and Wardas, P. (2004). Malondialdehyde as a lipid peroxidation marker. Pub Med. 57(9-10); 453-455.

8. Griendling, K. K. and FitzGerald, G.A. (2003). Oxidative stress and cardiovascular injury: Part I: basic mechanisms and in vivo monitoring of ROS. Circulation 108; 1912-1916.

9. Harrison, D., Griendling, K. K., Landmesser, U., Hornig, B. and Drexler, H. (2003). Role of oxidative stress in atherosclerosis. American Journal of Cardiology. 91;7A-11A.

10. Johnson, J. T., Iwang, E. U., Hemen, J. Z., Odey, M. O., Effiong, E. E. and Eteng, O. E. (2012). Evaluation of anti-nutrient contents of watermelon (Citrullus lanatus). Ann Biol Res. 3(11):5145-5150.

11. Keller, T., Zeller, T., Peetz, D., Tzikas, S., Roth, A., Czyz, E., Bickel, C., Baldus, S., Warnholtz, A., Frohlich, M., Sinning, C. R., Eleftheriadis, M. S., Wild, P. S., Schnabel, R. B., Lubos, E., Jachmann, N., Genth-Zotz, S., Post, F., Nicaud, V., Tiret,VL., Lackner, K. J., Munzel, T. F. and Blankenberg, S, (2009). Sensitive troponin I assay in early diagnosis of acute myocardial infarction. New England Journal of Medicine 361; 868-877.

12. Marklund, S. and Marklund, G. (1974). Involvement of superoxide anion radical in the autoxidation of pyrogallol and a convenient assay of superoxide dismutase. Eur. J. Biochem. 47(3); 469-73.

13. Mueller, C. F., Laude, K., McNally, J. S. and Harrison, D. G. (2005). ATVB infocus: redox mechanisms in blood vessels, Arteriosclerosis, Thrombosis, and Vascular Biology 25;274-278.

14. Nandi, A. and Chatterjea, I. B. (1988). Assay of superoxide dismutase activity in animal tissues. J. Bio sci. 13(3); 305-15.

15. Odinga, T., Essien, E. B. and Akaninwor, J. O. (2018). Prophylactic potency of Ricinodendron heudelotii seeds against aspirin-induced ulcer. Research journal of Life sciences, Bioinformatics, pharmaceuticals and Chemical sciences. 4(6); 664-671.

16. Odinga, T., Worlu-Wodu, Q. E. and Deekae, S. (2016) Bioprospective Screening of Ricinodendron heudelotii Seeds. J Anal Pharm
Res 3(7): 00084 DOI: 10.15406/japlr.2016.03.00084

17. Pompella, A., Visvikis, A., Paolicchi, A. L. and De Tata, V. (2003). The changing face of Glutathione, a cellular protagonist. Biochemical Pharmacology. 66(8); 1499-503.

18. Sedighi, O., Makhlough, A., Shokrzadeh, M. and Hoorshad, S. (2014). Association between Selenium and Glutathione peroxidase levels and severity of Diabetic Nephropathy in patients with type 2 Diabetes Mellitus. Nephro-urology monthly. 6(5); e21355.

19. Shlafer, M. and Marieb, E. (1989). The Nurse, Pharmacology and drug therapy. Addison Wesley, Menlopark, California.

20. Singh, W. L. (2011).Traditional medicinal plants of Manipur as anti-diabetics. J. Med. Plants Res. 5(5), 677-687.

21. Slatter, D. A., Bolton, C. H. and Bailey, A. J. (2000). The importance of lipid-derived malondialdehyde in diabetes mellitus. Diabetologia 43(2000); 550-557.

22. Somani, R. S., Jaina, K. S. and Singhai, A. K. (2007). Hypoglycemic activity of roots of Rubla cordifolla in normal and diabetic rats. Pharmacologyonline 1:162-169.

23. Satoh, K. (1978). Serum lipid peroxidation in cerberovascular disorders determined by new colorimetric method. Clin. Chem. ACTA. 90:37-43. https://doi. org/10.1016/0009-8981 (78)90081-5.

24. Uchida, K. (2000). Role of reactive aldehyde in cardiovascular diseases, Free Radical Biology and Medicine. 28(2000)1685-1696.

25. Wang, T. J. (2011). Assessing the role of circulating, genetic, and imaging biomarkers in cardiovascular risk prediction, Circulation 123; 551-565. 